\title{
The atmospheric potential of biogenic volatile organic compounds from needles of white pine (Pinus strobus) in Northern Michigan
}

\author{
S. Toma and S. Bertman \\ Department of Chemistry, Western Michigan University, 3425 Wood Hall, Kalamazoo, MI 49008, USA \\ Correspondence to: S. Bertman (steven.bertman@wmich.edu)
}

Received: 22 July 2011 - Published in Atmos. Chem. Phys. Discuss.: 28 September 2011

Revised: 2 February 2012 - Accepted: 15 February 2012 - Published: 29 February 2012

\begin{abstract}
The key role that biogenic volatile organic compounds (BVOC) play in atmospheric chemistry requires a detailed understanding of how BVOC concentrations will be affected by environmental change. Large-scale screening of BVOC emissions from whole forest ecosystems is difficult with enclosure methods. Leaf composition of BVOC, as a surrogate for direct emissions, can more easily reflect the distribution of BVOC compounds in a forest. In this study, BVOC composition in needles of 92 white pine trees (Pinus strobus), which are becoming a large part of Midwest forests, are tracked for three summers at the University of Michigan Biological Station (UMBS). $\alpha$-Pinene, the dominant terpene in all samples, accounts for $30-50 \%$ of all terpenes on a mole basis. The most abundant sesquiterpenoid was a $\mathrm{C} 15$ alcohol identified as germacrene D-4-ol. The relationship between limonene and total other monoterpenes shows two distinct trends in the population of these forests. About $14 \%(n=13)$ of the trees showed high levels of limonene (up to $36 \%$ of the total BVOC) in the same trees every year. Assuming that needle concentrations scale with emission rate, we estimate that hydroxyl radical reactivity due to reaction with monoterpenes from white pine increases approximately $6 \%$ at UMBS when these elevated concentrations are included. We suggest that chemotypic variation within forests has the potential to affect atmospheric chemistry and that large-scale screening of BVOC can be used to study the importance of $B V O C$ variation.
\end{abstract}

\section{Introduction}

Biogenic volatile organic compounds (BVOC) lead to the formation of tropospheric ozone in the presence of nitrogen oxides $\left(\mathrm{NO}_{\mathrm{x}}\right)$ (Atkinson, 2000) as well as to formation and growth of secondary organic aerosol (SOA) (Andreae, 2009; Laothawornkitkul et al., 2009). The total global estimated emission rate of $\mathrm{BVOC}$ is about $1.2 \times 10^{15} \mathrm{~g} \mathrm{C}$ per year, while the global anthropogenic VOC emission rate is about $1.0 \times 10^{14} \mathrm{~g} \mathrm{C}$ per year (Müller, 1992; Guenther et al., 1995). BVOC emissions in North America are dominated by isoprene $(51 \%)$, terpenes $(31 \%)$, and oxygenated VOC $(16 \%)$, based on hydroxyl radical $(\mathrm{OH})$ reactivity (Guenther et al., 2000). The organic component of aerosols (OA) is the largest single fraction with an average of $45 \%$ (Zhang et al., 2007), and recent research suggests that most of the OA mass is secondary (Jimenez et al., 2009). BVOC are believed to be the dominant contributors to global SOA formation due to their large global emissions and high reactivity with major oxidants in the atmosphere ( $\mathrm{Ng}$ et al., 2006). The mass of emission and atmospheric reactivity makes estimation of BVOC emission rates important. Foliage is the largest source of total global BVOC emissions, accounting for over $90 \%$ (Guenther et al., 1995). Hao et al. (2011) directly measured SOA yields from oxidation of real plant emissions and suggest that the specific chemical profile of BVOC emissions affects the SOA outcomes. Specific BVOC compound composition depends on the type of ecosystems, plant species composition, and environmental conditions. Peñuelas and Llusia (2001) suggested that emissions are controlled by plant VOC concentration, VOC vapor pressure or the resistance to VOC diffusion to the atmosphere. The factors controlling BVOC emissions

Published by Copernicus Publications on behalf of the European Geosciences Union. 
are complex and are still difficult to evaluate.

Several field studies have suggested that some atmospheric reactivity is not accounted for by current emission estimates in temperate forests of North America. Goldstein et al. (2004) showed that forest thinning dramatically enhanced monoterpene (MT) emission and ozone uptake in a California ponderosa pine plantation. They suggested that ozone uptake was due to reactions with unmeasured BVOC, with ozone reaction rates fast enough to allow oxidation within the forest canopy. Di Carlo et al. (2004) directly measured total $\mathrm{OH}$ reactivity in a northern Michigan forest, which was significantly greater than calculations based on measurements of individual compounds.

Emission rates, especially of terpenes, are related to vapor pressure within plant tissues and are greatly influenced by temperature (Guenther et al., 1995; Lerdau et al., 1997). BVOC emission rate estimates mostly have been derived from leaf or branch enclosure measurements (e.g., Ortega and Helmig, 2008; Ortega et al., 2008) with temperature and light corrections (Guenther et al., 1995). The amount of time and equipment required to make enclosure measurements poses logistical challenges for evaluating emissions in a large forest. Measuring BVOC concentration in leaves can be an alternative to the branch enclosure technique if there is a relationship between BVOC emission rate and their concentrations. Lerdau et al. $(1995,1994)$ studied the relationship of three MTs ( $\alpha$-pinene and $\beta$-pinene, and $\Delta$-carene) in ponderosa pine (1994) and Douglas-fir (1995). In ponderosa pine $\alpha$-pinene and $\beta$-pinene concentrations were positively related to emission rate, but this was not true for $\Delta$-carene. In Douglas-fir, all three terpenes showed a positive relationship. Lerdau et al. (1995) suggested that terpene concentrations in leaves could be used as an important parameter to predict emission rates in models. While the present work does not explicitly explore the relationship between gas-phase emissions and needle concentrations, the relationship is plausible since the profile of compounds within a needle likely is related to gas-phase emissions scaled by volatility. Measuring BVOC concentrations in leaves provides a benchmark for potential BVOC emissions in a whole forest and allows easy measurement of a large number of samples from a wide area in a short time and hence more precise estimation of the BVOC pool in the biomass of a forest.

Upper US Midwest forests are recovering from widespread logging and wildfires from the early 20th century (Frelich, 1995; Schmidt et al., 1996). Forest succession is allowing eastern white pine (Pinus strobus), once a dominant species in many parts of the Great Lakes region, to grow back to replace aspens (Bergen and Dronova, 2007; Ziegler, 2010). Succession from aspen forests to a higher representation of pines will cause "chemical succession" whereby isoprene gives way to terpenes in the atmosphere. This can lead to a number of atmospheric implications and to issues of forest health. For instance, Lee et al. (2006b) report that terpenes, especially sesquiterpenes (SQT), produce
SOA in higher yields than isoprene from photooxidation. Analysis of white pine needles provides baseline information about the pools of BVOC available in the growing forest and helps predict future atmospheric BVOC composition in the Midwest. This work reports BVOC levels in white pine needles in Northern Michigan measured over three growing seasons and attempts to estimate the atmospheric influence of chemotypic diversity within this population of white pine.

\section{Material and methods}

Sampling was performed at the University of Michigan Biological Station, (UMBS), $\left(45^{\circ} 30^{\prime} \mathrm{N}, 84^{\circ} 42^{\prime} \mathrm{W}\right)$ during summers of 2008, 2009, and 2010. Two forest sites located within a kilometer of each other in the same environment with similar soil conditions and with similar forest cover types were sampled. One forest was an intact, early successional forest (Ameriflux) and the other has been disturbed (FASET). A detailed map of relative distribution of sampled trees in the forests is shown in Fig. 1. In the FASET forest, early successional tree species (aspen and birch) were selectively girdled in Spring 2008, which is accelerating the growth of late successional species such as white pine (Nave et al., 2011). The present cover type of the UMBS forest is aspen $(60.9 \%)$, northern hardwoods such as maple and american beech (16.6\%), and white and red pines $(13.3 \%)$ (Bergen and Dronova, 2007).

Primarily understory white pine trees were sampled at Ameriflux $(n=35)$ and FASET $(n=36)$. Two trees were unable to be sampled after 2008 and 21 trees (11 at Ameriflux and 10 at FASET) were added in 2010. Year-old needles were collected from the southern branches at $1.3 \mathrm{~m}$ and stored at $-80^{\circ} \mathrm{C}$ until extraction, which was conducted within one month. In addition, needles were sampled from the top $(6-17 \mathrm{~m})$ and bottom $(2-4 \mathrm{~m})$ of the same large canopy trees $(n=4,2008 ; n=8,2009 ; n=10,2010)$. Frozen needles $(0.2 \mathrm{~g})$ were cut into small pieces $(5 \mathrm{~mm})$ and were soaked in $45 \mathrm{ml}$ hexane (with $100 \mu \mathrm{moll}^{-1}$ tridecane added as internal standard) for $24 \mathrm{~h}$ at $23.0^{\circ} \mathrm{C}$. The extracted solution was analyzed by gas chromatography-mass spectrometry (GCMS). The instrumentation, parameters, and calibration methods are described in supporting material. The dry mass in grams $(\mathrm{dwg})$ of needles was obtained by heating the residue at $55^{\circ} \mathrm{C}$ for $24 \mathrm{~h}$ after extraction. SPSS 16 (SPSS Inc., USA) was used to calculate statistical significance.

\section{Results and discussion}

\subsection{Understory trees}

Table 1 lists average concentrations of the 13 major compounds that accounted for more than $90 \%$ of the total area in the chromatograms of understory trees. The same BVOC compounds were observed in all three years and in both 


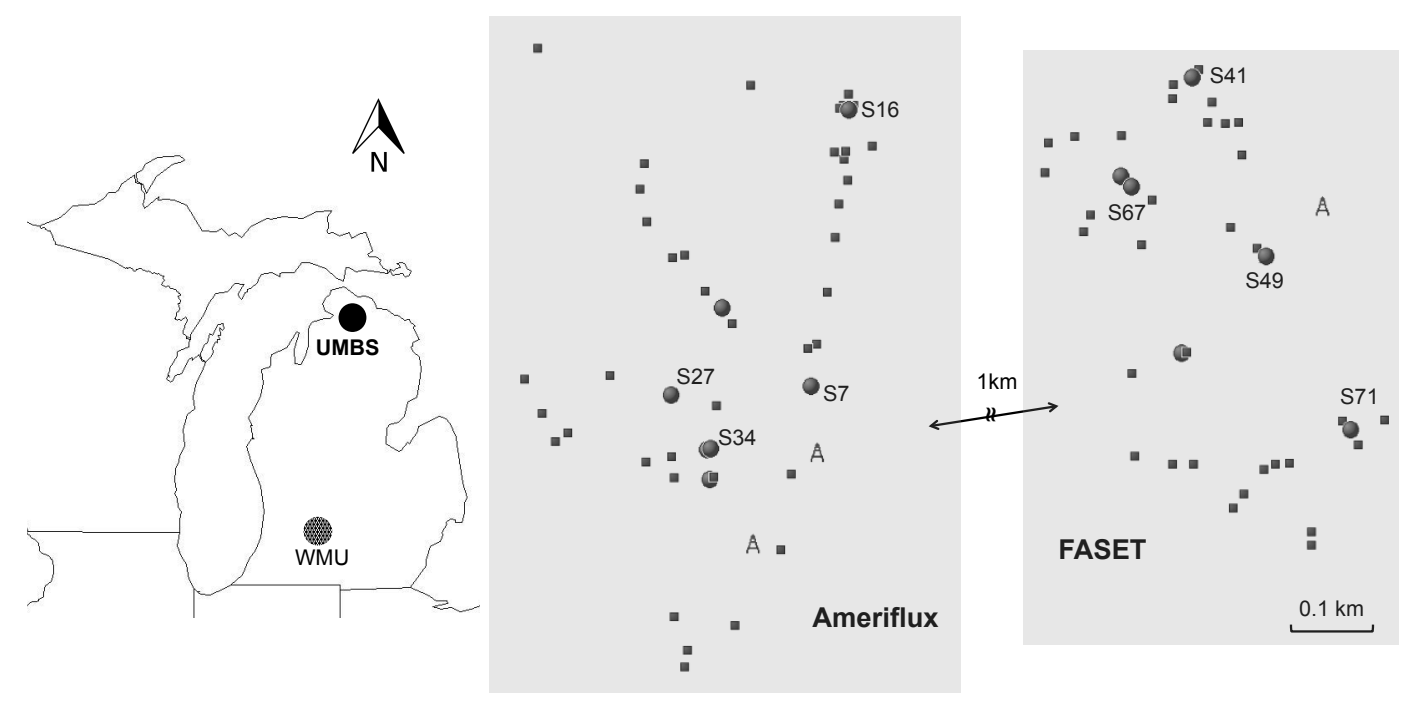

Fig. 1. Distribution of individual trees within the sampling site at UMBS. Squares: each understory tree, circles: trees with relatively high concentration of limonene.

forests. Concentrations did not show statistically significant differences between the two forests. Despite girdling in the FASET site, the forest structure had not been dramatically affected as of 2010, and this was reflected in the analysis of needles. Therefore, the data from both forests were combined in Table 1. The dominant terpene in all samples was $\alpha$-pinene, which accounts for $30-50 \%$ of all terpenes on a mole basis. The most aboundant SQT was germacrene D. A previous report of pines needles in Ontario and Wisconsin showed some of the same terpenes, including germacrene D and a related alcohol, as observed in this study (Hunt et al., 1990).

The concentration of total BVOC did not change significantly over the three years, although partitioning between total MT and total SQT showed that MT and SQT concentrations in 2009 were significantly different than in 2008 and 2010. In 2009, total MT showed higher concentrations and a wider range of standard deviations than in 2008 and 2010. In contrast, total SQT concentration was lower in 2009 than in 2008 and 2010. In conifers, MT and SQT are produced by different biosynthetic pathways (e.g. Martin et al., 2002). MT are formed from geranyl diphosphate with monoterpene synthase in plastids, while SQT are formed from farnesyl diphosphate with sesquiterpene synthases in the cytoplasm. Given that 2009 was a cooler summer (average temperature at UMBS in 2009 was $17.8^{\circ} \mathrm{C}$, about $2-3^{\circ} \mathrm{C}$ cooler than in 2008 or 2010), the different responses of MT and SQT might be related to enzyme activity and environmental factors such as light and temperature. While the impact of ambient temperature on terpenes in white pine has not been studied specifically, it is known that temperature influences terpene synthase activity (e.g. Grote and Niinemets, 2008). Also, there is evidence that temperature can affect ter- pene concentration in needles of at least one species of pines (Blanch et al., 2009). This one environmental factor is not solely responsible for differences but is representative of different overall growing conditions that might have influenced the absolute levels of compounds measured. Differences in environmental conditions appear not, though, to affect the chemotypic ratio of MT, as discussed later.

\subsection{Canopy (overstory) trees}

Table 2 shows the height variation of average concentrations of BVOC in needles from the top and the bottom of large trees that occupy the forest overstory. A small number of trees were sampled in the FASET forest in 2008 and a larger number was sampled in the Ameriflux forest in 2009 and 2010. Average concentrations of MT at the top of trees were 30-50\% higher than at the bottom, while SQT levels do not have as consistent a trend. The data suggest SQT are largely the same at the top and at the bottom. The average of total BVOC in needles at the top of the canopy trees is also larger than understory trees by about $50 \%$. The bottom needles of canopy trees essentially have the same composition as understory trees. A comparison of needles from the bottom of canopy trees and needles from understory trees for total MT, total SQT, and total BVOC in 2008-2010 using the non-parametric Mann-Whitney Test shows no statistical difference $(P<0.05)$. This suggests that terpene concentrations will increase as understory white pine trees grow into the canopy in the course of forest succession.

Differences in both light and temperature properties at each location in the canopy could affect these concentrations. Needles on large canopy trees exist in different light environments at the top and the bottom and a temperature gradient 
Table 1. The average concentration $\left(\mu \mathrm{mol} \mathrm{dwg} \mathrm{g}^{-1}\right)$ with standard deviation in needles of understory white pine trees at UMBS.

\begin{tabular}{lrrr}
\hline Year & $\begin{array}{r}2008 \\
(n=71)\end{array}$ & $\begin{array}{r}2009 \\
(n=70)\end{array}$ & $\begin{array}{r}2010 \\
(n=69)\end{array}$ \\
\hline MT & & & \\
\hline$\alpha-$ Pinene & $14.5( \pm 5.1)$ & $23.6( \pm 11.3)$ & $18.7( \pm 8.8)$ \\
Camphene & $2.2( \pm 1.1)$ & $2.8( \pm 1.9)$ & $2.5( \pm 1.6)$ \\
$\beta$-Pinene & $4.4( \pm 1.7)$ & $5.5( \pm 2.9)$ & $4.4( \pm 2.1)$ \\
Myrcene & $2.4( \pm 1.5)$ & $4.1( \pm 3.2)$ & $2.1( \pm 1.6)$ \\
$\alpha-$ Phellandrene & $1.0( \pm 0.4)$ & $0.9( \pm 0.8)$ & $0.9( \pm 0.4)$ \\
Limonene & $2.2( \pm 1.6)$ & $1.3( \pm 2.7)$ & $1.5( \pm 2.5)$ \\
$\beta-$ Phellandrene & & $1.5( \pm 1.0)$ & $1.2( \pm 0.7)$ \\
Terpinolene & $0.2( \pm 0.1)$ & N.D. & $0.4( \pm 0.1)$ \\
\hline SQT & & & \\
\hline$\beta-$ Caryophyllene & $1.0( \pm 0.3)$ & $0.1( \pm 0.2)$ & $1.2( \pm 0.3)$ \\
Germacrene D & $4.7( \pm 1.9)$ & $3.2( \pm 1.6)$ & $4.7( \pm 2.4)$ \\
Germacrene B & $1.2( \pm 0.4)$ & $0.4( \pm 0.4)$ & $1.6( \pm 0.6)$ \\
$\gamma, \delta$-Cadinene & $2.0( \pm 1.0)$ & $0.1( \pm 0.2)$ & $1.9( \pm 1.1)$ \\
Germacrene D-4-ol & $8.6( \pm 5.5)$ & $2.3( \pm 2.0)$ & $8.0( \pm 5.6)$ \\
\hline Total MT & $28.6( \pm 8.7)$ & $39.7( \pm 17.5)$ & $31.5(13.4)$ \\
Total SQT & $17.8( \pm 8.1)$ & $6.1( \pm 3.5)$ & $17.4( \pm 8.6)$ \\
Total BVOC & $46.5( \pm 15.0)$ & $45.8( \pm 19.7)$ & $48.9( \pm 20.5)$ \\
\hline
\end{tabular}

*limonene was not completely separated from $\beta$-phellandrene in 2008.

of several degrees can exist between the top and bottom of a forested environment (Gu et al., 1999). Terpene emissions into the atmosphere tend to be more sensitive to temperature than light because terpenes are stored within the leaf (Lerdau et al., 1994). Still, light dependent synthesis has been seen in expanding conifer needles (Lerdau and Gray, 2003). Results in Table 2 support the suggestion by Gleizes et al. (1980), who reported that synthesis of MT is more sensitive to photodependent activation than SQT, that light exposure may contribute differently to production of MT than to SQT. They showed that there is no MT formation without light, but there is, SQT formation in both light and dark. Determining the drivers of the variation of terpene levels at different place in the canopy will require further study.

\subsection{Sesquiterpene alcohol}

Surprisingly, after $\alpha$-pinene, one of the most abundant compounds consistently seen in field samples was a sesquiterpene alcohol, tentatively identified as germacrene D-4-ol (CAS\# 72120-50-4). Several experiments showed that this compound was not an artifact of sampling. Authentic standards of germacrene D-4-ol are not commercially available, so identification was made by indirect methods. A mass spectrum of the compound in a field sample and in the NIST 98 MS library are shown in Fig. 2. These spectra are almost identical. The presence of the hydroxyl group was confirmed by derivatization of a field sample to the TMS ether (the MS spectrum of the derivatized compound is shown in Fig. S1).

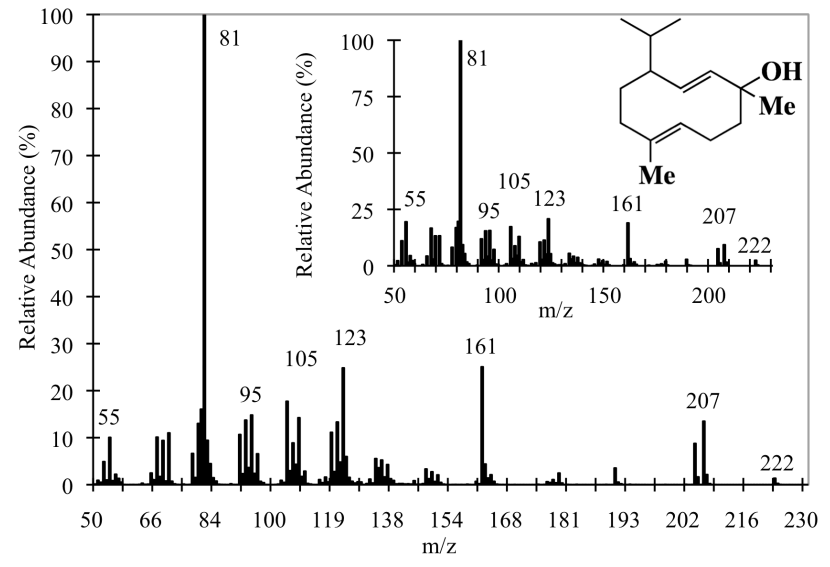

Fig. 2. Mass spectrum of germacrene D-4-ol from a field sample and from the NIST mass spectral library (embedded) with a proposed structure.

The concentrations of germacrene D-4-ol vary in concert with other SQT and so may indicate that this compound is produced and stored via similar mechanisms as SQT. Using the same response factor determined with standards of SQT to quantify this alcohol, we estimate that its concentrations in white pine needles can be upwards of $50 \%$ of $\alpha$-pinene on a mole basis.

Germacrene D-4-ol (or its isomers) has been reported in the sap of several pine species where it appears to protect trees from attack by various insects and has been cited in analyses of essential oils (Nevalainen and Koskinen, 2002; Smitt and Hogberg, 2002; Taweel et al., 2004). No report of this compound in the atmosphere has been made and little is known about its gas-phase properties. Estimated/calculated physical properties (ACD/Labs) suggest that germacrene D4-ol is a high-boiling compound with a vapor pressure much lower ( 5 orders of magnitude) than that of the monoterpenes and about $300 \times$ lower than that of germacrene D. While the hydroxyl group makes it more polar and thus less volatile than most SQT, it likely retains much of the increased reactivity with ozone. While this suggests that the compound may not be found in high concentration in the gas phase, it could exist on forest surfaces and contribute to $\mathrm{OH}$ reactivity and could have higher yield of SOA in the atmosphere (Lee et al., 2006a).

\subsection{Chemotypic variation within population}

Ortega et al. (2008) reported basal emission rates from seven white pine trees over the 2004-2006 growing seasons at UMBS and other places with total MT constituting 76.0$98.7 \%$ of terpenes and total SQT constituting $1.3-24.0 \%$. The BVOC species observed in this work and their distribution profiles in needles are substantially different from reported gas-phase values. $\alpha$-Pinene was the dominant MT in the gas phase, similar to the needles from this work, 
Table 2. Average concentration $\left(\mu \mathrm{mol} \mathrm{dwg}{ }^{-1}\right)$ of terpenes at the top $(6-17 \mathrm{~m})$ and bottom $(2-4 \mathrm{~m})$ of overstory trees.

\begin{tabular}{llrrr}
\hline Year & & Total MT & Total SQT & Total BVOC \\
\hline \multirow{2}{*}{$2008(n=4)$} & Top & $* 33.7$ & 12.3 & 46.0 \\
& Bottom & 25.1 & $* 21.0$ & 46.1 \\
\hline \multirow{2}{*}{$2009(n=8)$} & Top & $* 57.1$ & 5.5 & $* 62.6$ \\
& Bottom & 29.2 & 5.2 & 34.4 \\
\hline \multirow{2}{*}{$2010(n=10)$} & Top & $* 46.3$ & 12.8 & $* 59.1$ \\
& Bottom & 24.9 & 12.3 & 37.3 \\
\hline
\end{tabular}

* statistically significant difference between top and bottom of needles based on a Wilcoxon signed ranks test $(P=0.05)$. 2008 measurements made in FASET; 2009 and 2010 in Ameriflux.

but SQTs in gas phase were present in lower amounts and showed different composition. The difference between BVOC concentrations reported in the gas-phase and measured in needles is likely related to volatility differences. However, in contrast to compounds found in needles, $\beta$ caryophyllene was present in higher amounts in the gasphase than germacrene $\mathrm{D}$, and $\alpha$-farnesene, which was a dominant SQT in the gas phase, was not seen in needles collected at UMBS. The atmospheric effect of BVOC from white pine in northern Michigan forest could be evaluated by needle concentrations if the quantitative relationship between needle concentrations of specific BVOC and their gasphase emission rates was determined. Unfortunately, these data were not collected in this work.

Working from the assumption that there is a positive correlation between needle concentrations and gas-phase emissions, as seen in some species (Lerdau et al., 1994, 1995), an estimate can be made of the magnitude of impact that differences in emissions from individuals within a population might have. Chemotypic variation among individuals in a population of plants is not uncommon, as described by the essential oils industry (e.g. Tamir et al., 2011). For instance, six chemotypes of foliar monoterpenes were observed in the Australian Tea Tree (Keszei et al., 2010) and the frequency of chemotypes in this plant varied by sampling site. Sesquiterpene formation was independent of the monoterpene chemotype of an individual. Similar chemotypic variation in high emitting trees, such as the pines, could affect atmospheric chemistry depending on the extent and magnitude of the variation. About $14 \%$ of the trees sampled at UMBS (13/92 trees) showed anomalously high levels of limonene, comprising up to $36 \%$ of the total BVOC in needles. In the majority of samples the relative composition of limonene was about $3 \%$. The relationship between limonene and the sum of other MT (OMT) clearly shows two distinct trends, designated Mode I and Mode II in Fig. 3. This phenomenon was observed in specific trees and always the same trees every year. Changes in volatile compounds can be induced via en-

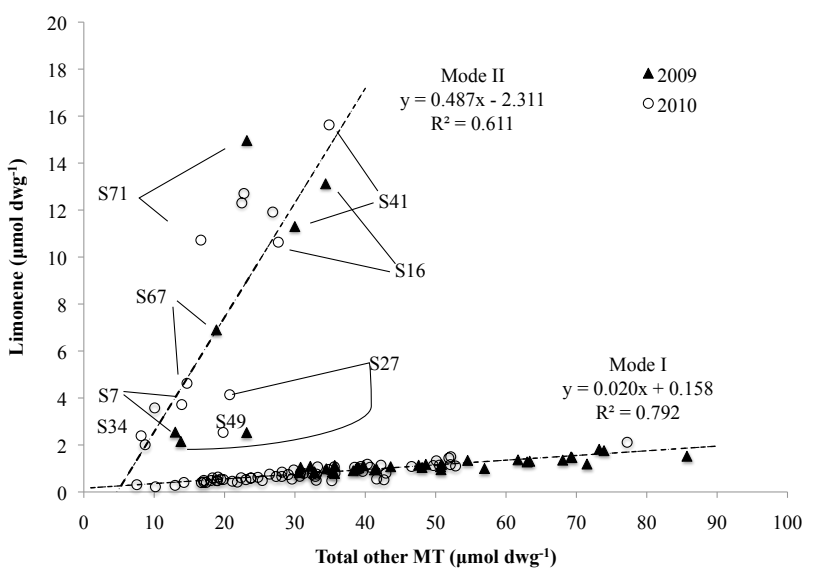

Fig. 3. The correlation between limonene and total other monoterpenes concentration at UMBS in 2009 and 2010. Data from 2008 are not included because limonene was not adequately resolved by the GC (see Supplement).

zyme activity. Martin et al. $(2002,2003)$ studied resin composition of Norway spruce in bark and wood before and after treatment with methyl jasmonate, to mimic insect damage. Limonene concentration was tremendously enhanced after the induction, but the activity of MT and SQT synthases declined 15 days after treatment. Were the bimodal behavior in the ratio of limonene/OMT in white pine to result from induction of environmental variations several patterns would be predicted. First, it is less likely that only two clear modes would be apparent, yet the same two modes are seen each year. Second, the chemotypes of at least some of the Mode II trees are likely to change with time during the growing season. Separate samples from representative trees at Ameriflux of Mode I and Mode II trees were tracked from June to August in 2010. Even though absolute concentrations of OMT and limonene changed as the growing season progressed, the limonene/OMT ratio for each tree stayed in the same mode (see Fig. S2). A more expansive study spanning several seasons (April-October in 2010) was conducted with samples from the WMU campus. This study also showed that the ratio of limonene and OMT did not change throughout the summer (see Fig. S3) and reflected one of the same modes seen at UMBS. Third, the mode of limonene/OMT ratio would follow environmental parameters. Trees in Mode II were not necessarily close to each other and were randomly distributed in the forest. In some cases, trees of both modes were within $2 \mathrm{~m}$ of each other at UMBS (Fig. 1), so environmental parameters were likely to be very similar. Several environment factors, such as light environment, tree age, and DBH were recorded for each sample, but there were no statistically significant correlations of Mode I/Mode II ratios with any of these factors. Hence, the data suggest that the bimodal behavior in the ratio of these two compounds is not related to environmental factors but is more likely due to 
genetic difference. Establishing a genetic basis for chemotypic variation can be challenging (Shelton et al., 2002), although expression of the genes involved in BVOC synthesis positively correlate with their emission rates. There is still much to be learned about the regulation of BVOC synthesis rates (Laothawornkitkul et al. (2009). Because there is a high degree of genetic variability in white pine, which occupies a wide distribution over very diverse environments (Buchert, 1994), it is reasonable to expect variation in BVOC production within a population. One piece of evidence in support of a genetic basis comes from chiral GC, which showed that (-)limonene is almost exclusively responsible for the increased ratio of limonene/OMT in trees exhibiting Mode II behavior in trees at UMBS (unpublished data). The levels of (+)limonene do not change much from tree to tree or from year to year.

If the biosynthesis of terpenes and emissions into the atmosphere vary within a population as a result of genotypic variation and lead to different pools of BVOC, emission rates based on a limited sampling could result in systematic error in emission estimates. For instance, in the present case, limonene emission over the forests in northern Michigan could be underestimated. To assess the impact of Mode II levels of limonene on atmospheric chemistry the $\mathrm{OH}$ reactivity change was estimated. Limonene $\mathrm{OH}$ reactivity can be expressed relative to OMT (physical and kinetic paramters for SQT are too uncertain).

$$
\begin{aligned}
& \frac{d[\mathrm{OH}]}{d t}=\left(1+\frac{k_{\text {Limonene }}[\text { Limonene }]}{k_{\mathrm{OMT}}[\mathrm{OMT}]}\right) k_{\mathrm{OMT}}[\mathrm{OMT}] \\
& \frac{d[\mathrm{OH}]}{d t}=\gamma\left(k_{\mathrm{OMT}}[\mathrm{OMT}]\right)
\end{aligned}
$$

where $\gamma$ is the contribution of limonene to $\mathrm{OH}$ reactivity relative to the rest of the MT. If BVOC emissions from white pine needles scales with needle concentration and temperature based on Raoult's Law, $\gamma$ can be derived from the measured ratio in pine needles (Fig. 3),

$$
\frac{[\text { Limonene }]}{[\mathrm{OMT}]}=\frac{P_{\mathrm{Lim} .}}{P_{\mathrm{OMT}}}=\frac{X_{\text {Lim. }} P_{\text {Lim. }^{\circ}}}{X_{\mathrm{OMT}} P_{\mathrm{OMT}^{\circ}}}
$$

where $P$ is the partial vapor pressure of a component, $X$ is the mole fraction, and $P$ is the vapor pressure of the pure substance. Parameters for $P^{\circ}$ and $k$ are shown in the supplementary materials. The relative contributions to $\mathrm{OH}$ reactivity, $\gamma$, for each compound were calculated at $298 \mathrm{~K}$ for Mode I $\left(\gamma_{\mathrm{I}}=1.02\right)$, Mode II $\left(\gamma_{\mathrm{II}}=1.41\right)$, and a mixture of Modes I and II $\left(\gamma_{\text {I\&II }}=1.08\right)$ based on the distribution observed at UMBS. $X_{\mathrm{Lim}} / X_{\mathrm{MT}}$ are obtained by the slope of regression lines in Fig. 3. The effect of limonene is small in Mode I, contributing about $2 \%$ of OMT contribution to $\mathrm{OH}$ reactivity. Using the mixture of trees in both Mode I and Mode II that is observed at UMBS suggests that the limonene contribution to $\mathrm{OH}$ reactivity is about $6 \%$ higher than when considering only pure Mode I, the most abundant chemotype.
As these young forests at UMBS and the upper Midwest continue to transition, terpenes will begin to rival or replace isoprene as the dominant BVOC in the near-canopy atmosphere. Since limonene reacts faster with ozone as well as with $\mathrm{OH}$ and yields more SOA than $\alpha$-pinene, individual tree variation within the forest population of white pine could be a significant factor in the BVOC impact on atmospheric chemistry.

\section{Summary}

As white pine increases in abundance across the US Midwest, the chemical composition of BVOC in forest canopies will be more represented by MT. In white pine needles the most abundant 13 compounds accounted for more than $90 \%$ of the BVOC, of which $\alpha$-pinene was the major contributor. Absolute concentrations varied over the course of a growing season and also interannually. In 2009, total MT showed $32 \%$ larger concentration and a wider range of standard deviations than in 2008 and 2010. In contrast, total SQT species were $65 \%$ lower in concentration in 2009 than in 2008 and 2010. Position within the canopy affects BVOC composition in needles as well, with total MT consistently higher in needles at the top of the canopy. So changes in both area coverage and canopy structure will influence atmospheric composition. Germacrene D-4-ol was measured to constitute a large fraction of the BVOC mass in needles, but further study will be needed to determine the gas-phase behavior and its role in canopy chemistry and SOA formation. Approximately $14 \%$ of the trees at UMBS contain relatively high levels of limonene. The ratio between limonene and OMT concentrations in needles did not change seasonally or from year-to-year. Including this chemotypic variation among individuals, limonene contribution to $\mathrm{OH}$ reactivity increases about $6 \%$ at UMBS. This is an indicator of the potential error in BVOC emissions estimates and suggests that chemotypic differences within forest populations, which are easier to determine by looking at the needle concentrations, should be considered.

\section{Supplementary material related to this article is available online at: http://www.atmos-chem-phys.net/12/2245/2012/ acp-12-2245-2012-supplement.pdf.}

Acknowledgements. This research was supported by the NSF through grant ATM-0904147. We thank the staff of UMBS for all their assistance in the field, John Seeley, Oakland University, for discussions about analytical approaches, Hideo Naoki and Shiono Koryo Kaisha, Ltd. for providing essential oils. We thank Doug Williams and David Bolliet (KALSEC) for help with chiral GC, and also thank Jesse Thompson, Todd Barkman, and David Karowe for their help. 
Edited by: J. Fuentes

\section{References}

Advanced Chemistry Development (ACD/Labs) Software V11.02, (C)1994-2012 ACD/Labs, Canada, 2012.

Andreae, M. O.: A new look at aging aerosols, Science, 326, 14931494, 2009.

Atkinson, R.: Atmospheric chemistry of VOCs and $\mathrm{NO}_{\mathrm{x}}$, Atmos. Environ., 34, 2063-2101, 2000.

Bergen, K. M. and Dronova, I.: Observing succession on aspendominated landscapes using a remote sensing-ecosystem approach, Landscape Ecol., 22, 1395-1410, doi:10.1007/s10980007-9119-1, 2007.

Blanch, J. S., Peñuelas, J., Sardans, J., and Llusiá, J.: Drought, warming and soil fertilization effects on leaf volatile terpene concentrations in Pinus halepensis and Quercus ilex, Acta Physiol. Plant., 31, 207-218, doi:10.1007/S11738-008-0221-Z, 2009.

Buchert, G. P.: Genetics of White Pine and Implications for Management and Conservation, Forest. Chron., 70, 427-434, 1994.

Di Carlo, P., Brune, W. H., Martinez, M., Harder, H., Lesher, R., Ren, X., Thornberry, T., Carroll, M. A., Young, V., Shepson, P. B., Riemer, D., Apel, E., and Campbell, C.: Missing OH reactivity in a forest: Evidence for unknown reactive biogenic VOCs, Science, 304, 722-725, 2004.

Frelich, L. E.: Old forest in the Lake States today and before European settlement, Nat. Area. J., 15, 157-167, 1995.

Gleizes, M., Pauly, G., Bernarddagan, C., and Jacques, R.: Effects of Light on Terpene Hydrocarbon Synthesis in Pinus-Pinaster, Physiol. Plant., 50, 16-20, 1980.

Goldstein, A., McKay, M., Kurpius, M., Schade, G., Lee, A., Holzinger, R., and Rasmussen, R.: Forest thinning experiment confirms ozone deposition to forest canopy is dominated by reaction with biogenic VOCs, Geophys. Res. Lett., 31, L22106, doi:10.1029/2004GL021259, 2004.

Grote, R. and Niinemets, Ü.: Modeling volatile isoprenoid emissions - a story with split ends, Plant Biol., 10, 8-28, 2008.

Gu, L. H., Shugart, H. H., Fuentes, J. D., Black, T. A., and Shewchuk, S. R.: Micrometeorology, biophysical exchanges and NEE decomposition in a two-story boreal forest - development and test of an integrated model, Agr. Forest. Meteorol., 94, 12348, 1999.

Guenther, A., Hewitt, C. N., Erickson, D., Fall, R., Geron, C., Graedel, T., Harley, P., Klinger, L., Lerdau, M., Mckay, W. A., Pierce, T., Scholes, B., Steinbrecher, R., Tallamraju, R., Taylor, J., and Zimmerman, P.: A Global-Model of Natural Volatile Organic-Compound Emissions, J. Geophys. Res.-Atmos., 100, 8873-8892, 1995.

Guenther, A., Geron, C., Pierce, T., Lamb, B., Harley, P., and Fall, R.: Natural emissions of non-methane volatile organic compounds, carbon monoxide, and oxides of nitrogen from North America, Atmos. Environ., 34, 2205-2230, 2000.

Hao, L. Q., Romakkaniemi, S., Yli-Pirilä, P., Joutsensaari, J., Kortelainen, A., Kroll, J. H., Miettinen, P., Vaattovaara, P., Tiitta, P., Jaatinen, A., Kajos, M. K., Holopainen, J. K., Heijari, J., Rinne, J., Kulmala, M., Worsnop, D. R., Smith, J. N., and Laaksonen, A.: Mass yields of secondary organic aerosols from the oxidation of $\alpha$-pinene and real plant emissions, Atmos. Chem. Phys., 11, 1367-1378, doi:10.5194/acp-11-1367-2011, 2011.

Hunt, R., Meagher, M., and Manville, J.: Morphological and foliar terpene characters to distinguish between western and eastern white pine, Can. J. Bot., 68, 2525-2530, 1990.

Jimenez, J. L., Canagaratna, M. R., Donahue, N. M., Prevot, A. S. H., Zhang, Q., Kroll, J. H., DeCarlo, P. F., Allan, J. D., Coe, H., Ng, N. L., Aiken, A. C., Docherty, K. S., Ulbrich, I. M., Grieshop, A. P., Robinson, A. L., Duplissy, J., Smith, J. D., Wilson, K. R., Lanz, V. A., Hueglin, C., Sun, Y. L., Tian, J., Laaksonen, A., Raatikainen, T., Rautiainen, J., Vaattovaara, P., Ehn, M., Kulmala, M., Tomlinson, J. M., Collins, D. R., Cubison, M. J., Dunlea, E. J., Huffman, J. A., Onasch, T. B., Alfarra, M. R., Williams, P. I., Bower, K., Kondo, Y., Schneider, J., Drewnick, F., Borrmann, S., Weimer, S., Demerjian, K., Salcedo, D., Cottrell, L., Griffin, R., Takami, A., Miyoshi, T., Hatakeyama, S., Shimono, A., Sun, J. Y., Zhang, Y. M., Dzepina, K., Kimmel, J. R., Sueper, D., Jayne, J. T., Herndon, S. C., Trimborn, A. M., Williams, L. R., Wood, E. C., Middlebrook, A. M., Kolb, C. E., Baltensperger, U., and Worsnop, D. R.: Evolution of Organic Aerosols in the Atmosphere, Science, 326, 1525-1529, doi:10.1126/Science.1180353, 2009 .

Keszei, A., Hassan, Y., and Foley, W. J.: A Biochemical Interpretation of Terpene Chemotypes in Melaleuca alternifolia, J. Chem Ecol., 36, 652-661, doi:10.1007/S10886-010-9798-Y, 2010.

Laothawornkitkul, J., Taylor, J. E., Paul, N. D., and Hewitt, C. N.: Biogenic volatile organic compounds in the Earth system, New Phytol., 183, 27-51, 2009.

Lee, A., Goldstein, A. H., Keywood, M. D., Gao, S., Varutbangkul, V., Bahreini, R., Ng, N. L., Flagan, R. C., and Seinfeld, J. H.: Gas-phase products and secondary aerosol yields from the ozonolysis of ten different terpenes, J. Geophys. Res., 111, D07302, doi:10.1029/2005JD006437, 2006a.

Lee, A., Goldstein, A. H., Kroll, J. H., Ng, N. L., Varutbangkul, V., Flagan, R. C., and Seinfeld, J. H.: Gas-phase products and secondary aerosol yields from the photooxidation of 16 different terpenes, J. Geophys. Res., 111, D17305, doi:10.1029/2006JD007050, 2006b.

Lerdau, M., Dilts, S. B., Westberg, H., Lamb, B. K., and Allwine, E. J.: Monoterpene emission from ponderosa pine, J. Geophys. Res., 99, 16609-16615, 1994.

Lerdau, M., Matson, P., Fall, R., and Monson, R.: Ecological controls over monoterpene emissions from Douglas-fir (Pseudotsuga menziesii), Ecology, 76, 2640-2647, 1995.

Lerdau, M., Guenther, A., and Monson, R.: Plant production and emission of volatile organic compounds, Bioscience, 47, 373383, 1997.

Lerdau, M. and Gray, D.: Ecology and evolution of light-dependent and light-independent phytogenic volatile organic carbon, New Phytol., 157, 199-211, 2003.

Martin, D., Tholl, D., Gershenzon, J., and Bohlmann, J.: Methyl jasmonate induces traumatic resin ducts, terpenoid resin biosynthesis, and terpenoid accumulation in developing xylem of Norway spruce stems, Plant Physiol., 129, 1003-1018, doi:10.1104/pp.011001, 2002.

Martin, D. M., Gershenzon, J., and Bohlmann, J.: Induction of volatile terpene biosynthesis and diurnal emission by methyl jasmonate in foliage of Norway spruce, Plant Physiol., 132, 15861599, doi:10.1104/Pp.103.021196, 2003. 
Müller, J. F.: Geographical-Distribution and Seasonal-Variation of Surface Emissions and Deposition Velocities of Atmospheric Trace Gases, J. Geophys. Res.-Atmos., 97, 3787-3804, 1992.

Nave, L. E.,. Gough, C. M., Maurer, K. D., Bohrer, G., Hardiman, B. S., Le Moine, J., Munoz, A. B., Nadelhoffer, K. J., Sparks, J. P., Strahm, B. D., Vogel, C. S., and Curtis, P. S.: Disturbance and the resilience of coupled carbon and nitrogen cycling in a north temperate forest, J. Geophys. Res., 116, G04016, doi:10.1029/2011JG001758, 2011.

Nevalainen, M. and Koskinen, A. M. P.: Total Synthesis of nor-1, 6-Germacradien-5-ols, J. Org. Chem., 67, 1554-1560, 2002.

Ng, N. L., Kroll, J. H., Keywood, M. D., Bahreini, R., Varutbangkul, V., Flagan, R. C., Seinfeld, J. H., Lee, A., and Goldstein, A. H.: Contribution of first-versus second-generation products to secondary organic aerosols formed in the oxidation of biogenic hydrocarbons, Environmental science \& technology, 40, 2283-2297, \{Ng, 2006 \#60\}, 2006.

Ortega, J. and Helmig, D.: Approaches for quantifying reactive and low-volatility biogenic organic compound emissions by vegetation enclosure techniques-Part A, Chemosphere, 72, 343-364, 2008.

Ortega, J., Helmig, D., Daly, R., Tanner, D., Guenther, A., and Herrick, J.: Approaches for quantifying reactive and low-volatility biogenic organic compound emissions by vegetation enclosure techniques - Part B: Applications, Chemosphere, 72, 365-380, 2008.

Peñuelas, J. and Llusia, J.: The complexity of factors driving volatile organic compound emissions by plants, Biol. Plantarum, 44, 481-487, 2001.

Schmidt, T., Spencer, J., and Hansen, M.: Old and potential old forest in the Lake States, USA, Forest Ecol. Manag., 86, 81-96, 1996.
Shelton, D., Aitken, K., Doimo, L., Leach, D., Baverstock, P., and Henry, R.: Genetic control of monoterpene composition in the essential oil of Melaleuca alternifolia (Cheel), Theor. Appl. Genet., 105, 377-383, doi:10.1007/S00122-002-0948-7, 2002.

Smitt, O. and Hogberg, H.: First Total Synthesis of (-)-1(10),5Germacradien-4-ol, Synlett, 8, 1273-1276, 2002.

Tamir, H., Satovic, Z., Gorelick, J., Danin, A., Fischer, R., Chaimovitsh, D., and Dudai, N.: Intraspecific Variation of Chiliadenus iphionoides Essential Oil in Israel, Chem. Biodivers., 8, 1065-1082, 2011.

Taweel, Areej M. AL, Kadriya S. EL- Deeb, and Farid J. ALMuhtadi: Chemical Composition and Antimicrobial activity of the essential oil of Kleinia odora, Saudi Pharm. J., 12, 47-50, 2004.

Zhang, Q., Jimenez, J. L., Canagaratna, M. R., Allan, J. D., Coe, H., Ulbrich, I., Alfarra, M. R., Takami, A., Middlebrook, A M., Sun, Y. L., Dzepina, K., Dunlea, E., Docherty, K., DeCarlo, P. F., Salcedo, D., Onasch, T., Jayne, J. T., Miyoshi, T., Shimono, A., Hatakeyama, S., Takegawa, N., Kondo, Y., Schneider, J., Drewnick, F., Borrmann, S., Weimer, S., Demerjian, K., Williams, P., Bower, K., Bahreini, R., Cottrell, L., Griffin, R. J., Rautiainen, J., Sun, J. Y., Zhang, Y. M., and Worsnop, D. R.: Ubiquity and dominance of oxygenated species in organic aerosols in anthropogenically-influenced Northern Hemisphere midlatitudes, Geophys. Res. Lett., 34, L13801, doi:10.1029/2007GL029979, 2007.

Ziegler, S. S.: The Past and Future of White Pine Forests in the Great Lakes Region, Geography Compass, 4, 1179-1202, 2010. 